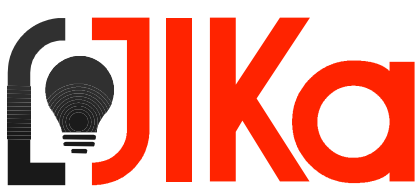

JURNAL INOVASI \& KREATIVITAS
JURNAL INOVASI DAN KREATIVITAS (JIKa)

Volume 1 Nomor 1 2021; p-ISSN 2776-1843

Doi: dx.doi.org/10.30656/JIKa.v1i1.3282

https://e-jurnal.Ippmunsera.org/index.php/JIKa

SK No. 0005.27761843/K.4/SK.ISSN/2021

\title{
PERSEPSI RISIKO FISIK DAN PSIKOLOGIS \\ TERHADAP MINAT MENGGUNAKAN COMMUTER LINE DI INDONESIA
}

\author{
PERCEPTION OF PHYSICAL AND PSYCHOLOGICAL RISKS \\ ON THE INTEREST OF USING LINE COMMUTER IN INDONESIA
}

\begin{abstract}
Naya Oktaviani Pratiwi, Amarul
Program Studi Manajemen, Fakultas Ekonomi dan Bisnis, Universitas Serang Raya nayaoktavianipratiwi@gmail.com, amarulunsera@gmail.com
\end{abstract}

\section{Abstract}

Problems: Commuter line transportation passengers experience physical risks and psychological risks that harm passengers and cause trauma, are hesitant and do not want to use the Commuter Line services.

Purpose: To analyze physical risk perceptions and psychological perceptions of interest using a commuter line.

Methodology: This study uses a verification method with a quantitative approach. This study uses two independent variables and one dependent variable, or what is known as the dependent variable. The two independent variables are the perception of physical and psychological risks, and the dependent variable is engaging with a sample size of 40 respondents.

Results/Findings: Perceptions of physical risk positively affect interest in using commuter line transportation. Perceptions of psychological risk have a negative effect on interest in using commuter line transportation. The independent variable simultaneously has a positive effect on the dependent variable.

Paper Type: field research

Keywords: Commuter Line; Interest; Physical Risk; Psychological Risk 
Masalah: Penumpang transportasi commuter line mengalami risiko fisik dan risiko psikologis yang berdampak negatif terhadap penumpang dan menjadikan trauma, raguragu dan tidak ingin menggunakan jasa Commuter Line.

Tujuan: menganalisis persepsi risiko fisik dan persepsi psikologi terhadap minat menggunakan commuter line.

Metodologi: Penelitian ini menggunakan metode verifikatif dengan pendekatan kuantitatif. Penelitian ini menggunakan dua variabel yang terdiri dari dua variabel independen dan satu variabel dependen atau yang dikenal dengan variabel terikat. Dua variabel independen itu adalah persepsi risiko fisik dan psikologis dan variabel dependennya adalah minat dengan jumlah sampel 40 responden.

Temuan/Hasil Penelitian: Persepsi risiko fisik berpengaruh positif terhadap minat menggunakan transportasi commuter line. Persepsi risiko psikologis berpengaruh negatif terhadap minat menggunakan transportasi commuter line. Variabel independen secara simultan berpengaruh positif terhadap variabel dependen.

Jenis penelitian: Riset lapangan

Kata kunci: Commuter Line; Minat; Risiko Fisik; Risiko Psikologis

\section{A. PENDAHULUAN}

KRL (Commuter Line), adalah kereta api listrik yang digunakan sarana transportasi. KRL dipilih karena kemampuannya mengangkut muatan dan penumpang dalam jumlah besar untuk jarak jauh dan sedang, serta sebagai sarana angkutan Commuter di kota-kota besar. Di wilayah Jakarta dan sekitarnya, operasional KRL merupa $\mathrm{k}$ kan tanggungjawab KA Jabodetabek (atau disebut juga KRL Commuter Line, dulu dikenal sebagai KRL Jabodetabek) Banyak penumpang yang mengguna-kan jasa transportasi commuter line mengalami kejadian tidak diinginkan seperti adanya pelecehan seksual, kejahatan, adanya trauma yang dirasa-kan, dan lain sebagainya yang disebab-kan kapasitas penumpang yang sangat banyak sehingga terjadi desakan antar penumpang.

Survei KRPA (Koalisi Ruang Publik Aman) menunjukkan sepanjang tahun 2019 , hampir $50 \%$ penumpang perempuan mengalami pelecehan seksual di transportasi publik di berbagai kota di Indonesia (BBC News, 2019). Survei ini melibatkan 38.766 responden perempuan dari 34 provinsi dengan latar belakang usia maupun tingkat pendidikan yang beragam. Risiko yang sering atau pernah dialami penumpang transportasi Commuter Line yaitu risiko fisik dan persepsi psikologis dimana risiko tersebut berdampak negatif terhadap penum $\neg$ pang dan menjadikan trauma, ragu-ragu dan tidak ingin menggunakan jasa Commuter Line lagi.

Risiko fisik didefinisikan sebagai risiko yang terkait dengan bahaya fisik karena penggunaan produk/layanan (Ikhsan, 2020). Kemungkinan risiko fisik akan mendorong individu untuk berhenti menggunakan layanan di masa mendatang. Kemungkinan kerugian yang dapat membahayakan mereka secara fisik seperti pelecehan, perampokan dll. sehingga mereka cenderung berhenti menggunakan layanan ini lagi. Risiko psikologis terkait dengan situasi yang membuat konsumen merasa tidak nyaman dan tekanan psikologis karena mengguna-kan produk atau layanan. Penelitian ini bertujuan untuk mengetahui pengaruh persepsi risiko fisik dan persepsi risiko psikologi 
terhadap minat menggunakan commuter line.

\section{B. TINJAUAN PUSTAKA DAN PENGAMBILAN HIPOTESIS}

\section{Risiko Fisik}

Persepsi risiko merupakan suatu anggapan tentang ketidakpastian dan konsekuensi yang tidak diingin $\neg$ kan dalam melakukan suatu kegiatan tertentu (Andriyano \& Rahmawati, 2016). Fenomena ketidakpastian dan ketidaknyamanan yang dihadapi konsumen dalam proses pembelian membuat keputusan mereka tidak dapat diramalkan konsekuensi negatif yang mempengaruhi proses peng-ambil $\neg$ an keputusan pembelian produk atau jasa tersebut (Rahim, 2017). Keputusan konsumen untuk memodi-fikasi, menunda, atau menghindari keputusan pembelian ini sangat di-pengaruhi oleh risiko yang dipikir $\neg$ kan (Ong, 2013).

Indikator persepsi risiko fisik antara lain (Ikhsan, 2020):

1. Kejahatan, yaitu suatu kondisi yang terjadi pada penumpang Commuter line yang bersifat asusila dan merugikan, dan menimbulkan ketidaktenangan pada penumpang dalam Commuter Line.

2. Terluka, yaitu suatu kondisi dimana ada serangan dari penumpang lain baik disengaja maupun tidak disengaja sehingga membuat penumpang yang terluka merasa tidak nyaman dalam Commuter Line.

3. Pelecehan, yaitu suatu tindakan yang dilakukan penumpang lain kepada orang yang menjadi korban pelecehan secara fisik dilakukan misalnya: colekan atau sentuhan, gerakan atau isyarat sehingga membuat penumpang merasa tidak nyaman, tersinggung, direndahkan martabatnya.

\section{Risiko Psikologis}

Risiko psikologis merupakan potensi kerugian self-esteem dari frustasi karena tujuan membeli sebuah produk tidak tercapai (Chairunnisa \& Siregar, 2019). Dimensi risiko psikologis adalah perasaan yang dirasakan, emosi, atau ego yang akan dirasakan oleh konsumen karena mengkonsumsi, membeli atau penggunaan suatu produk (Ariani, 2017). Persepsi Risiko Psikologis didefinisikan sebagai risiko bahwa pemilihan atau kinerja produsen akan memiliki efek negatif pada perdamaian konsumen pikiran atau persepsi itu (Rahim, 2017). Berdasarkan definisi tersebut dapat disimpulkan bahwa persepsi risiko psikologis adalah dampak negatif atau kerugian yang dialami seseorang setelah menggunakan jasa atau produk tertentu yang berakibat buruk.

\section{Minat}

Minat perilaku adalah suatu keinginan atau minat seseorang untuk melakukan suatu perilaku tertentu (Rahayu, 2016). Minat tidak selalu statis dapat berubah dengan ber-jalannya waktu. Minat adalah suatu keinginan seseorang untuk melakukan suatu perilaku tertentu. Seseorang melakukan suatu perilaku tertentu jika mempunyai keinginan atau minat melakukanya. Manusia biasanya berperilaku dengan cara yang sadar bahwa mereka mempertimbangkan informasi yang tersedia, dan secara implisit dan eksplisit juga memper-timbangkan implikasi dari tindakan-tindakan yang dilakukan.

Minat adalah sesuatu yang timbul setelah menerima rangsangan dari produk yang dilihatnya, kemudian timbul ketertarikan untuk mencoba produk tersebut dan akhirnya timbul keinginan untuk membeli dan memiliki produk tersebut (Wibowo et al., 2015). Minat adalah suatu keadaan dalam diri seseorang pada dimensi kemungkinan subyektif yang meliputi hubungan antara orang itu sendiri dengan beberapa tindakan (Pratama \& Suputra, 2019). Faktor-faktor yang mempengaruhi minat adalah sebagai berikut (Savitri \& Tukiman, 2019):

1. Faktor Internal, adalah sesuatu yang membuat berminat yang datangnya 
dari dalam diri seseorang. Faktor internal adalah pemusatan perhatian, keingin-tahuan, motivasi dan kebutuhan.

2. Faktor Eksternal, adalah sesuatu yang membuat berminat yang datangnya dari luar diri, seperti: keluarga, rekan, tersedia prasarana dan sarana atau fasilitas dan keadaan

\section{Hipotesis}

Perumusan hipotesis dalam penelitian ini adalah sebagai berikut:

1. H1: Diduga Terdapat pengaruh antara Persepsi Risiko Fisik dan Persepsi Risiko Psikologis ter-hadap Minat Menggunakan Commuter Line Indonesia di Rangkas Bitung Kabupaten Lebak.

2. H2: Diduga Terdapat pengaruh antara Persepsi Risiko Psikologis terhadap Minat Menggunakan Commuter Line Indonesia di Rangkas Bitung Kabupaten Lebak.

3. H3: Diduga secara simultan terdapat pengaruh antara Persepsi Risiko Fisik dan Persepsi Risiko Psikologis terhadap Minat Menggunakan Commuter Line Indonesia di Rangkas Bitung Kabupaten Lebak.

\section{METODE PENELITIAN}

Metode penelitian yang digunakan dalam penelitian ini adalah metode verifikatif dengan pendekatan kuantitatif. Menurut Ardianto (2011) variabel yang diteliti bisa satu, dua, tiga atau lebih. Metode verifikatif adalah metode metode yang bertujuan untuk menguji hipotesis dengan mengguna $\neg$ kan metode statistik inferensial (Salmah, 2019).

Populasi dalam penelitian ini adalah masyarakat pengguna commuter line yang berada di Rangkas Bitung Kabupaten. Penentuan jumlah sampel adalah ukuran sampel yang diambil dapat ditentukan dengan cara mengalikan jumlah variabel dengan 5, atau $5 \mathrm{x}$ jumlah variabel (Malhotra \& Dash, 2016). Dengan demikian jumlah sampel dalam penelitian ini yaitu 40 responden.

\section{HASIL PEMBAHASAN}

\section{Karakteristik Responden}

Karakteristik responden dengan rentang usia di bawah 20 tahun sampai di atas 40 tahun. Jumlah responden dengan yang dominan berada pada rentang usia 20-29 Tahun (32,5 \%) dan 30\% berada pada rentang waktu 30-39 Tahun (Tabel 1). Responden paling kecil berada pada usia > 40 Tahun.

Tabel 4.1

Karakteristik Responden Berdasarkan

Usia

\begin{tabular}{|c|c|c|c|}
\hline No & Keterangan & $\mathbf{F}$ & $\mathbf{\%}$ \\
\hline 1 & $<20$ Tahun & 10 & $25 \%$ \\
\hline 2 & $20-29$ Tahun & 13 & $32,5 \%$ \\
\hline 3 & $30-39$ Tahun & 12 & $30 \%$ \\
\hline 4 & $>40$ Tahun & 5 & $12,5 \%$ \\
\hline \multicolumn{2}{r|}{ Total } & $\mathbf{4 0}$ & $\mathbf{1 0 0} \%$ \\
\hline
\end{tabular}

\section{Risiko Fisik ( $\left.\mathrm{X}_{\mathbf{1}}\right)$}

Setelah pengujian Parsial dilakukan diperoleh $\mathrm{dk}=\mathrm{n}-2(40-2=38)$ dengan nilai $t_{\text {hitung }}$ sebesar 1,686. Hipotesis dapat diterima jika nilai $t_{\text {hitung }}>t_{\text {tabel. }}$. Berdasarkan tabel t parsial di atas, diperoleh nilai untuk $\mathrm{X}_{1}$ (Persepsi risiko fisik) adalah $t_{\text {hitung }}$ $(6.118)>t_{\text {tabel }}(1,686)$. Dengan demikian hipotesis untuk $\mathrm{X}_{1}$ (Persepsi risiko fisik) $\left(\mathrm{H}_{1}\right)$ dapat diterima atau dengan kata lain terdapat pengaruh dari variabel independen $\mathrm{X}_{1}$ (Persepsi risiko fisik) terhadap variabel dependen $Y$ (minat menggunakan).Maka penelitian ini berhasil membuktikan hipotesis pertama yang diajukan yaitu persepsi risiko fisik berpengaruh terhadap minat menggunakan commuter line.

\section{Risiko psikologi $\left(\mathrm{X}_{2}\right)$}


Hasil pengujian Parsial dilakukan diperoleh $\mathrm{dk}=\mathrm{n}-2 \quad(40-2=38)$ dengan nilai $t_{\text {hitung sebesar 1,686. Hipotesis dapat }}$ diterima jika nilai $t_{\text {hitung }}>t_{\text {tabel. }}$. Hasil $u j i t$ parsial untuk variabel $\mathrm{X}_{2}\left(\mathrm{H}_{2}\right)$ diperoleh nilait $_{\text {hitung }} 3.818>t_{\text {tabel }}(1,686)$. Dengan demikian hipotesis untuk $\mathrm{X}_{2}\left(\mathrm{H}_{2}\right)$ diterima atau dengan kata lain terdapat pengaruh negative dari variabel independen $\mathrm{X}_{2}$ (Persepsi risiko psikologis) terhadap variabel dependen Y (minat menggunakan commuter line).

\section{Risiko Fisik $\left(X_{1}\right)$ dan Risiko psikologi $\left(X_{2}\right)$ terhadap Minat menggunakan ( $Y$ )}

Setelah pengujian Simultan dilakukan diperoleh nilai $\mathrm{F}_{\text {Hitung }}=19.871$ sedangkan nilai $\mathrm{F}_{\text {tabel }}(\mathrm{df}=\mathrm{n}-\mathrm{k}-1=40-2-1=37)$ sebesar 4,11 dengan demikian dapat dikatakan bahwa $\quad F_{\text {hitung }}>F_{\text {Tabel }}$ (19.871>4,11). Dari hasil tersebut maka penelitian ini berhasil membuktikan hipotesis simultan $\left(\mathrm{H}_{3}\right)$ yaitu terdapat pengaruh positif secara simultan dari Variabel Independen terhadap Variabel Dependen.

\section{E. PENUTUP}

Berdasarkan analisis data yang telah dilakukan dan pembahasan yang telah dikemukakan pada bab sebelumnya, dapatditarik beberapa kesimpulan, yaitu: Persepsi risiko fisik berpengaruh positif terhadap minat menggunakan, hal ini dibuktikan dengan hasil uji $t$ parsial diperoleh nilai $t_{\text {hitung }} 6.118>t_{\text {tabel }}$ 1,686. Persepsi risiko psikologis berpengaruhnegative terhadap minat menggunakan, hal ini dibuktikan dengan hasil uji $t$ parsial diperoleh nilai $t$ hitung $3.818>t$ tabel 1,686. Dari kedua variabel diatas yang memilii pengaruh yang lebih tinggi adalah variabel risiko fisik. Oleh karena itu bagi Perusahaan PT. KCI (Commuter Line), diharapkan dapat meningkatkan keamanan dan kenyamanan penumpang dalam menggunakan transportasi Commuter Line. Misalkan dengan adanya cctv dalam setiap gerbongCommuter line, adanya peraturan/hukuman yang diterapkan bagi penumpang yang melakukan tindakan asusila terhadap penumpang lain.

\section{DAFTAR PUSTAKA}

Andriyano, Y. (2016). Pengaruh Persepsi Kemudahan, Persepsi Kebermanfaatan, Persepsi Risiko dan Kepercayaan terhadap Minat Menggunakan RekeningPonsel. Jurnal ProfitaEdisi 2 tahun 2016.

Ardianto, Elvinaro. 2011. Metodologi Penelitian untuk Public Relations Kuantitatif dan Kualitatif. Bandung : Simbiosa Rekatama Media

Ariani, M dan Zulhawati. (2017). Pengaruh Kualitas, Keamanan, dan Risiko terhadap Minat menggunakan Line pay.Conference On Management and Behavioral Studies, 12 Oktober 2017.

BBC News. (2019). Ribuan perempuan dilecehkan di transportasi umum, "saya harus selalu waspada setiap naik kereta dan bus."

https://www.bbc.com/indonesia/indon esia-50570430

Chairunnisa, F dan Siregar M Ridha. (2019). Pengaruh Risiko Fisik dan Risiko Psikologis terhadap Niat Berkujung Kembali yang Dimedia sioleh Citra Kognitif Pada Wisatawan Di Kota Banda Aceh, JurnalIlmiah, (4, 3 , Hal 375-390).

Ikhsan, K and Sunaryo D . (2020). Technology Acceptance Model, Social Influence And Preceived Risk in Using Mobile Applications: Empirical Evidence In Online Transportation In Indonesia.

Malhotra, N. K., \& Dash, S. (2016). Marketing research: An applied orientation. Pearson,. 
Ong, I. A. (2013). Analisa pengaruh strategi diferensiasi, citra merek, kualitas produk dan harga terhadap keputusan pembelian pelanggan di Cincao Station Grand City, Surabaya. Jurnal Strategi Pemasaran, 1(2), 1-11. http://publication.petra.ac.id/index.ph $p / m a n$ a j e m e n pemasaran/article/view/668

Pratama, A. B., \& Suputra, I. D. G. D. (2019). Pengaruh Persepsi Manfaat, Persepsi Kemudahan Penggunaan, dan Tingkat Kepercayaan Pada Minat Menggunakan Uang Elektronik. EJurnal Akuntansi, 27(2), 927-953. https://ocs.unud.ac.id/index.php/Akunt ansi/article/view/45848

Rahayu, I. S. (2016). Minat Nasabah Menggunakan Mobile Banking Dengan Menggunakan Kerangka Technology Acceptance Model (TAM)(Studi Kasus PT Bank Syariah Mandiri Cabang Yogyakarta). JESI (Jurnal Ekonomi Syariah Indonesia), 5(2), 137. https://doi.org/10.21927/jesi.2015.5(2 ).137-150
Rahim, H.(2017). Analisis Pengaruh Persepsi Risiko, dan Kepercayaan terhadap Minat Transaksi Penggunaan Paytren Pada PT. Vettra Sentosa Internasional. Jurnal EKOBITEK, (6.2, Hal 274-286).

Salmah, Ninin Non Ayu. 2015. Pengaruh Stress Kerja Dan Kepuasan Kerja Terhadap Kinerja Karyawan Pada PTPN VII Cinta Manis. (Vol 12, No 2, Juli 2015).

Savitri, A.A dan Tukiman (2019) Faktorfaktor yang Mempengaruhi Minat Masyarakat dalam Menggunakan Transportas iBaru "Surboyo Bus" di Kota Surabaya.JurnalllmuAdmiistrasi Negara, $(9,2)$.

Wibowo, F.S et al. (2015). Pengaruh Persepsi Manfaat, Persepsi Kemudahan, Fitur Layanan, dan Kepercayaan terhadap Minat Menggunakan E-money Card ( StudiPadapenggunaJasa Commuter Line Di Jakata.Jurnal Riset Manajemen Sains Indonesia (JRMSI), ( $6,1)$. 